\title{
Standard Moroccan Berber Language
}

National Cancer Institute

\section{Source}

National Cancer Institute. Standard Moroccan Berber Language. NCI Thesaurus. Code C154207.

The standardized national variety of Berber spoken in Morocco. 